\title{
From Biowastes to Potent Anticancer Leads Evaluation from Peel of Zingiber officinale Linn.
}

\author{
Shaileyee Das and Subhash C Mandal* \\ Pharmacognosy and Phytotherapy Research Laboratory, Division of Pharmacognosy, Department of Pharmaceutical Technology, Jadavpur University, Kolkata, \\ West Bengal, INDIA.
}

\begin{abstract}
Objectives: Zingiber officinale Linn. is a rhizome commonly consumed as a culinary purpose, medicine or spice in India. The aim of this study was to evaluate potent anticancer leads from ginger rhizome peel. Methods: Cytotoxicity study was carried out by using brine shrimp, Antimitotic study was carried out through onion root method, Anti-proliferating study was carried out using in vitro cell line study and at last the cell viability study was carried out through yeast model using quantitative and qualitative methods. Results: $\mathrm{LC}_{50}$ of phenolic group contain fraction (PHGF) of Petroleum ether fraction (PEF) was found to be $18 \mu \mathrm{g} / \mathrm{ml}$, which was threefold higher than that of synthetic standard podophyllotoxin, i.e., 50 $\mu \mathrm{g} / \mathrm{ml}$. 2 isolated compounds (6-shogaol and 6-gingerol) have good HSF1 inhibition activity and creating apoptosis. 6-shogaol showed good Green fluorescent protein (GFP) at $10 \mu \mathrm{g} / \mathrm{ml}$ and 6-gingerol compound good GFP at only $5 \mu \mathrm{g} / \mathrm{ml}$. In MTT assay cell viability was showing $\pm 54 \%$ in ginger peel extract sample dose of $100 \mu \mathrm{g} / \mathrm{ml}$. When the pet ether fraction of ginger peel extract was tested, result showed the $\pm 96 \%$ cell death in dose of $100 \mu \mathrm{g} / \mathrm{ml}$. We observed cell viability of c. $90 \%, 60 \%$ and $94 \%$ in the
\end{abstract}

case of the wild-type strain. Conclusion: This study revealed the strong antiproliferative potentials of Petroleum ether fraction (PEF) of extract of Ginger peel. It was also found to be moderately safe for consumption and thus could serve as a source of candidate for the development of new antiproliferative and antimicrobial drugs.

Key words: Anticancer, Antiproliferative, Anti-mitotic, Yeast model, Zingiber officinale Linn.

\section{Correspondence}

Dr. Subhash C Mandal

Pharmacognosy and Phytotherapy Research Laboratory, Division of Pharmacognosy, Department of Pharmaceutical Technology, Jadavpur University, Kolkata-700032, West Bengal, INDIA.

Phone: +919830986659

Email: scmandal1963@gmail.com

DOI: 10.5530/ijpi.2021.1.9

\section{INTRODUCTION}

Zingiber officinale Linn, Zingiberaceae (Ginger) is an extensively used in various foods and potions around the human kind and is utilized in traditional Indian and Chinese medicine. For centuries, ginger has been used in traditional Indian Ayurvedic medicine as Ginger in many cases, like as powdered rhizome, extract of rhizome, dried or steamed rhizomes, fresh rhizomes for the treatment of life expectancy, potency, memory, immunity, oxidant stress, skin complexion, gastrointestinal constipation, improves pronunciation mistakes, heart problems, common cold disorders, inflammation and helminthiasis. But only ginger peel efficacy in human health is not checked previously in traditional medicine. Ginger peel is wasted by people in various ways (like Food Processing industry, household culinary) and it increases environmental pollution by producing greenhouse gases. ${ }^{1}$ The most significant greenhouse gas produced from bio-waste is methane. It is released during the breakdown of organic matter in landfills. Several scientific studies have revealed that the peels of ginger contain a wide range of active ingredients that are responsible for its antioxidant, antimicrobial, anti-inflammatory, anticancer and spasmolytic and diuretic properties. The evaluating of certain polyphenols (such as flavonoids, phenolic acids, terpenoids and others) and their derivatives are mainly considerable for these potential health benefits.

Extraction is an essential first step for the isolation and refinement of these bio-active components of plant materials. Generally, the conventional extraction procedures (such as solvent extraction, steam distillation, etc.) are often limited by the elongated extraction time, environmental pollution, low yield and mass transfer resistances caused by the contribution of more than one phase in the system. To provide a useful alternative to the traditional extraction methods, new physical practices such microwave extraction processes and ultrasound have been applied to disrupt the cell wall and discharge active components during product extraction. Shogaol and Gingerol are known as the major phenolic oil of ginger oil especially in Zingiber officinale Linn. oil showing anticancer effects.

In recent years, extensive research has been done on cancer and depression, the two prime causes of mortality and morbidity in people, however there are two main problems: the first is the etiology and the second is the treatment of these diseases. ${ }^{2}$ indicated that cancer and depression are two independent risk factors for mortality rate in humans; hence, their effects on all-cause of mortality are additive, not synergistic.

Cervical and lung cancers are the principal causes of cancer-related death. Cervical cancer is caused by chronic infection with a range of highrisk Human Papilloma Virus (HPV) leading to an estimated 274,000 death globally every year. Moreover, lung cancer is a highly aggressive, progressive and heterogeneous malignant disease predominantly results from smoking tobacco with few options of treatment. For the treatment, chemotherapy with drugs such as Cisplatin and Iressa and psychotherapy with antidepressant drugs like fluoxetine, sertraline and citalopram are widely used. However, these drugs have several side effects leading to further research for treatment with herbal medicines to reduce adverse side effects. Insufficient attention has so far been devoted to Zingiber officinale Linn. Therefore, the goal of this study was to investigate the potential effects of Zingiber officinale Linn. on human colon cancer cell 


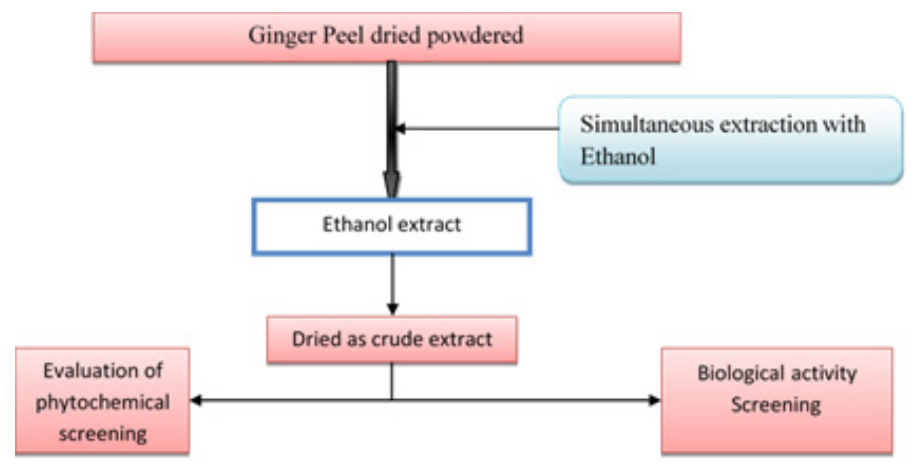

Flowchart for Experimental design.

growth in in vitro cell culture. My objective is to find potent anticancer leads from Biowastes of Zingiber officinale Linn. peels.

\section{MATERIALS AND METHODS}

\section{Experimental design}

\section{Chemicals}

From Sigma Aldrich (Bangalore, India) purchased bacterial strains like Staphylococcus aureus (S. aureus, ATCC 6538), L. monocytogenes (L. monocytogenes ATCC 19115), Salmonella typhi (Salmonella typhi. ATCC 19430), Escherichia coli (E. coli ATCC 8099), 3-(4,5-dimethylthiazol2-yl)-2,5-diphenyltetrazolium (MTT) reagent, Cyclophosphamide, dimethyl sulfoxide (DMSO), Norfloxacin TZ, podophyllotoxin, doxorubicin. Wild yeast, ethylenediaminetetraacetic acid (EDTA), Dulbecco's modified Eagle's medium (DMEM), propidium iodide (PI), fatal bovine serum (FBS) Media and trypsin were obtained from Himedia Ltd., (Mumbai, (India)). Other chemicals and solvents were obtained from Merck India, Loba Chemicals (India) and SD Fine Chemicals (Mumbai, India).

\section{Plant material}

Ginger was purchased from local market of Kolkata and the outer dry and semi-dry layers and the apical trimmings of yellowish brown-skin ginger (Zingiber officinale Linn.) peel were collected immediately after processing from household cooking (Kolkata, India). ${ }^{3}$ The peels were dried in hot air oven thoroughly and ground with a mixture grinder, sieved by various mesh sized sieve and stored for the further experiments.

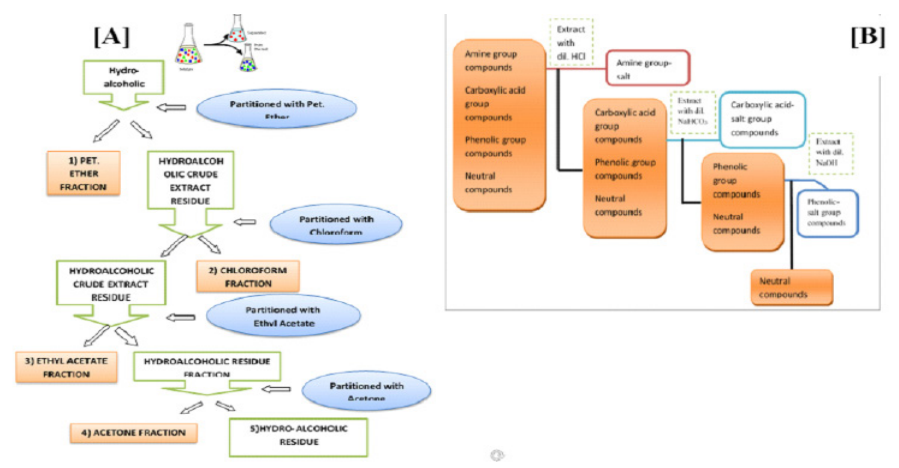

Figure 1: $[A]$ Extraction and Fractionations flow diagram, [B] Further fractionations from previous fractions.

\section{Extraction and fractionation}

As per (Figure $1[\mathrm{~A}]$ and $[\mathrm{B}])$, the dried ginger peel $(2 \mathrm{Kg})$ were ground and carried on microwave assisted extraction, Sonicated assisted extraction and cold macerated extraction (three types of extraction for optimization of chemical constituents in extract) with ethanol for $72 \mathrm{~h}^{3-5}$ The Ethanol extract was filtered and the filtrate was evaporated under reduced pressure at $40^{\circ} \mathrm{C}$ which yielded the crude extract $(481$ gm) ${ }^{6,7}$ A portion of the crude extract ( $400 \mathrm{~g}$ ) was successively fractioned to yield Pet ether (260 g), chloroform (40.6 g), Ethyl Acetate (24.2 g) and aqueous-methanol (156 g) fractions. Pet ether fraction was further fractionated by dil. $\mathrm{HCl}$, Sodium bicarbonate and sodium hydroxide for getting pure chemical group fractions. From total $(200 \mathrm{~g})$ pet ether fraction we got Amine group of compounds (21g), Carboxylic acid group contain fraction $(8 \mathrm{~g})$, phenolic group contain fraction (PHGF) $(167 \mathrm{~g})$ and neutral ionic compound fraction $(4 \mathrm{~g})$.

\section{Phytochemical analysis}

The qualitative and the quantitative analyses of ginger peel's constituents were carried out by the methodology described in the book ${ }^{8}$ by using TLC and test tube chemical analysis methods.

\section{Antifungal activity}

Antifungal activity of the ethanolic extract and subsequent fractions was measured by employing the agar tube dilution method against the selected pathogens. The molds and yeasts used in this study included Aspergillus flavus (ATCC32611, human pathogen), Candida albicans (ATCC2091, human pathogen) and Candida glabrata (ATCC90030, human pathogen) using the methods., ${ }^{3,-11}$ The strains were provided by Akansha Skin and hair Herbal Ltd. Industrial Culture Collection (Kolkata, India). Dilutions were made by the final concentration of the extracts, subsequent fractions and the standard drug to $200 \mu \mathrm{g} / \mathrm{ml}$ of SDA (Sabouraud Dextrose Agar). Miconazole (an antifungal medication used to treat ring worm, pityriasis versicolor and yeast infections of the skin or vagina) was used as the standard drug and the experiments were carried out in triplicates.

\section{Antibacterial activity}

Antibacterial activity of the ginger peel crude extract and subsequent factions were assessed against various Gram-positive and Gram-negative human pathogens by the agar disk diffusion protocol. Gram-positive bacteria (S. aureus and L. monocytogenes) $)^{3,9-11}$ and Gram-negative bacteria (Salmonella spp. and Escherichia coli) were used for this bioassay using the methods. These specific micro-organisms were selected due to the wellknown causes of these pathogens to food borne diseases. Staphylococcus aureus (S. aureus, ATCC 6538), L. monocytogenes (L. monocytogenes ATCC 19115), Salmonella typhi. (Salmonella typhi. ATCC 19430) and Escherichia coli (E. coli ATCC 8099) were provided by Akansha Skin and hair Herbal Ltd., Industrial Culture Collection (Kolkata, India). Norflox $\mathrm{TZ}$ was used as the standard antibacterial agent.

\section{Cytotoxicity assay}

A cytotoxicity assay was carried out by brine shrimp lethality bioassay. In this bioassay, the eggs of the brine shrimp a food for tropical fishes were collected from local pet fish store as and placed to hatch in a chamber with brine solution. ${ }^{12,13}$ After $48 \mathrm{~h}$, eggs hatched and the larvae (nauplii) were observed. The larvae were collected and transferred into the test tubes. 10 no.s larvae were transferred in each test tube containing different concentrations $(1,10,100,1000 \mu \mathrm{g} / \mathrm{ml})$ of the extracts and fractions, dose selected as per randomised study. Drug exposure were given to the larvae for $24 \mathrm{hr}$, then the numbers of dead larvae were counted and 
Das and Mandal.: From Biowastes to Potent Anticancer Leads Evaluation From Peel of Zingiber officinale Linn.

this data was used for estimate $\mathrm{LD}_{50}$ (Median Lethal Concentration 50). ${ }^{14}$ Podophyllotoxin was used as standard drug in this bioassay.

\section{Antimitotic assay}

Onion root tip method was used for Antimitotic activity study. ${ }^{15,16}$ Approximately equal sized onion bulbs (Allium cepa L.) near about $(40 \pm 10 \mathrm{~g})$ were obtained from the local vegetable market at Kolkata, West Bengal, India. The onion bulbs were grown in dark place for $48 \mathrm{~h}$ over 50 $\mathrm{ml}$ of purified water at ambient temperature for allowing the roots to be grown approximately $3 \mathrm{~cm}$. The bulbs with root tips developed up to 2-3 $\mathrm{cm}$ were selected for the study. The onion rooted bulbs were divided into five groups each group containing 3 bulbs. The first group provided as control. Immediately, the bulbs were placed in containers filled with test samples (one bulb in each) and control (purified water). Whole material was incubated at $22 \pm 3^{\circ} \mathrm{C}$ for $72 \mathrm{~h}$ and away from the direct sunlight. The length of the roots grown during incubation period of $72 \mathrm{hr}$ and grown. The root number and the mitotic index were recorded. The root tips (2-3 mm) were collected and were fixed in the fixing solution of acetic acid and ethanol (3:1). Onion root tip squash preparation was made for microscopic studies by stained with a mixture of acetocarmine and $1 \mathrm{~N} \mathrm{HCl}$ (9:1). Using high resolution (100x) bright field light microscopy, each root tip, the numbers of mitotic cells and total meristematic cells were counted manually. Good quality onions were rooted in water and the onion roots were treated with different concentrations of the extracts and various fractions and standard drug cyclophosphamide for $24 \mathrm{~h}$. The following formula has been used for calculated of Mitotic index:

Mitotic index $=\frac{\text { number of dividing cells }}{\text { number of non-dividing cells }}$

\section{Antiproliferation assay}

a) Cell Culture

HCT116 cells (Human Colon cancer cell line) ${ }^{16-18}$ were cultured according to the protocol provided by the depositor. HCT116 cells were grown in $10 \%$ MEM supplemented with FCS at $37^{\circ} \mathrm{C}$ under a humidified atmosphere of $5 \% \mathrm{CO}_{2}$. Gently gave passaging by using serological pipette. After proper passaging split the cells into 1:2, 1:3 ratio for cytotoxicity studies.

\section{b) HSF1 (HEAT SHOCK FACTOR 1) inhibition assay}

In order to study the HSF1 inhibition of a new drug, it is important to determine the inhibition concentration of the drug. ${ }^{16,17}$ GFP study by fluorescence microscope helps to detect the HSF1 inhibition of the drug. The concentration non-toxic to the cells is chosen for HSF1 inhibition assay. After $48 \mathrm{hr}$ of the addition of drug, cell death and GFP (Green Fluorescent Protein) was estimated. After $24 \mathrm{hr}$ addition of drugs heat shock incubation was given for $1 \mathrm{hr}$ at $39^{\circ} \mathrm{C}$. The result is confirmed by less GFP.

\section{c) Heat shock:}

After 24 hrs incubation the cytotoxicity was observed and plates were incubated for $1 \mathrm{hrs}$ at $39^{\circ} \mathrm{C}$ in heat shock incubator. ${ }^{16,17}$ After $1 \mathrm{hr}$ heat shock the plates were further incubated for $24 \mathrm{hrs}$ at $37^{\circ} \mathrm{C}$ in $5 \% \mathrm{CO}_{2}$ environment and observed for GFP by fluorescence microscope.

\section{d) 3-(4,5-dimethylthiazol-2-yl)-2,5-diphenyltetrazolium bromide (MTT) assay}

Antiproliferation assay was carried out via MTT assay. ${ }^{16,17}$ Cell proliferation, which imitates the normal function of mitochondria and cell viability. HCT116 cells were seeded at flat-bottomed 96-well culture plate with a ratio of $5 \times 104$ cells/well in DMEM. The cells were washed after $24 \mathrm{hrs}$ and cultured in a culture medium with different concentrations of Ginger peel extracts and various fractions (25 to 200 $\mu \mathrm{g} / \mathrm{ml}$, for $48 \mathrm{~h}$ and $72 \mathrm{~h}$ ). Non-FBS culture medium encompassing $10 \%$ MTT was added to each well of a microtitre plate and after that the samples were incubated for $4 \mathrm{~h}$ at $37^{\circ} \mathrm{C}$. After $4 \mathrm{~h}$ culture medium was removed and DMSO was added. Then the absorbance was read at $570 \mathrm{~nm}$ (ELISA reader). The noted absorbance of control cells (DMSO treated) was considered as $100 \%$. The following formula has been used for calculating the percentage cell viability:

Mean value of [(OD in control group - OD in treated group)

OD in control group

\section{Cell viability activity screening by yeast model:}

\section{i) Introduction of cell viability assay by yeast model}

The yeast Saccharomyces cerevisiae is a very beneficial model organism for studies of cellular response to numerous types of stresses. Fortitude of cell viability is one of the most frequently used methods in a study of cyto- or genotoxicity under dissimilar kinds of chemical, physical, or environmental factors. The analysis of the feasibility parameter is also very significant for industrial processes where micro-organisms are used. Generally, cell viability is defined as a $\%$ of live cells in a whole population.

\section{ii) Yeast strains and growth conditions}

The yeast strains were used mainly wild-type SP4 MATa leu1 $\arg 4^{19,20}$ Yeast was grown in a standard liquid YPD medium using of a rotary shaker at 150 r.p.m. A solid YPD medium yeast cells cultured at a temperature of $28^{\circ} \mathrm{C}$.

\section{iii) Cell viability assay method}

To determine cell viability, yeast cells culture was centrifuged, washed with sterile water and suspended to the final density of $10^{8}$ cells $\mathrm{mL}^{-1}$ in $100 \mathrm{mM}$ phosphate buffer at $\mathrm{pH} 7.0$, comprising $0.1 \%$ glucose, $1 \mathrm{mM}$ EDTA, $10 \mathrm{mM} \mathrm{H}_{2} \mathrm{O}_{2}$ and $0.105 \mathrm{mM}$ menadione, $0.4 \mathrm{mM}$ allyl alcohol. ${ }^{21,22}$ Then the $1 \mathrm{~h}$ incubation period, the yeast cells were pelleted with centrifugation, after that washed twice with sterile water. Suspended in a buffer solution.

To determine the cell viability and vitality, the methods were used:

1. Spotting test: Cells were suspended in sterile buffer solution. Diluted to give $10^{7}, 10^{6}, 10^{5} \mathrm{~mL}^{-1}$. Samples $(5 \mu \mathrm{L})$ of each suspension were inoculated on solid YPD medium. After that incubated at $28^{\circ} \mathrm{C}$ for $48 \mathrm{~h}$. At last the colony growth was inspected. ${ }^{22-24}$

2. Colony-forming units: Cells were suspended in sterile buffer solution and diluted to a final concentration of $10^{3}$ cells $\mathrm{mL}^{-1}$. A sample of 100 $\mu \mathrm{L}$ of the suspension was inoculated on solid YPD medium. Incubated at $28^{\circ} \mathrm{C}$ for further $48 \mathrm{~h}$. then the colony forming unit was counted. ${ }^{24-27}$

3. Staining with Methylene blue: Cells were suspended in PBS and cell suspension was mixed with $100 \mu \mathrm{L}$ methylene blue and incubated for $5 \mathrm{~min}$ at room temperature. ${ }^{28-30}$ Then the viability was examined under binocular microscope (QUASMO) with attached digital camera at 40x from at least 200 cells in one biological replicate. The dead cells were blue and viable cells were colourless in nature. The quantitative results were presented as mean $\pm \mathrm{SD}$.

\section{Statistical analysis}

The values were voiced as Mean \pm standard error of mean (SEM). Analysing the data by using one-way analysis of variance (ANOVA) using Graph-Pad Prism software. $p<0.05$ were considered as statistically significant. 


\section{RESULTS}

Through extraction, fractionations, isolations and purifications processes got GPEE $=$ Ginger Peel Ethanol Extract, $\mathrm{PEF}=$ Pet Ether Fraction, CF $=$ Chloroform Fraction, EAF $=$ Ethyl Acetate Fraction, $\mathrm{AMF}=$ Aquas Methanol Fraction, AGF $=$ Amino Group Fraction, $\mathrm{CGF}=$ Carboxylic Group Fraction, PHGF $=$ Phenolic Group Fraction, NCF $=$ Neutral Compound Fraction, two types of pure compounds 6-shogaol and 6-gingerol from ginger rhizome peels.

\section{Phytochemical Screening}

The results of phytochemical analysis showed the presence of alkaloids (34.6\%), flavonoids (4.8\%), glycosides $(2.4 \%)$, triterpenoids $(22.2 \%)$ and phenolic content (36\%) in Ginger peel extract and alkaloids $(0 \%)$, flavonoids (1.8\%), glycosides (1.0\%), triterpenoids (12.4\%) and phenolic content $(84.8 \%)$ in PEF.

\section{Antifungal activity}

The results obtained for the antifungal activity of the extract and subsequent fractions derived from Zingiber officinale Linn. peel against the tested pathogens. The most prominent antifungal activity was observed against Candida glabrata. The crude extract showed 85\% inhibition against this pathogen while pet ether fraction (PEF). Phenolic group fraction and carbonic group fractions inhibited the growth of Candida glabrata by $93 \pm 2 \%, 98 \pm 2 \%$ and $82 \pm 4$, respectively; $p$ $<0.05$ (Figure 2[A]). Pet ether, phenolic group fraction and carbonic group fractions showed antifungal activity against Candida albicans and inhibited its growth by $91 \pm 2 \%, 98 \pm 2 \%$ and $84 \pm 2 \%$, respectively; $p<0.05$. The other active fractions in this bioactivity were pet ether, phenolic group fraction and carbonic group fractions against A. flavus $(80 \pm 10 \%, 86 \pm 10 \%$ and $78 \pm 10 \%$ respectively; $p<0.05)$ (Figure $2[\mathrm{~A}])$.

\section{Antibacterial activity}

The extract and subsequent fractions derived from Zingiber officinale Linn. peel displayed a strong antibacterial activity against the tested organisms. The crude extract pet ether, phenolic group fraction and carbonic group fractions inhibited the growth of S. aurias only by $62 \%$, $82 \%$ and $84 \%$ as compared to standard drug (Norflox TZ). The crude extract pet ether, phenolic group fraction and carbonic group fractions inhibited the growth of $E$. coli by $76 \%, 96 \%$ and $97 \%$ as compared to standard drug (Norflox TZ). in (Figure 2[B]).

\section{Cytotoxicity assay}

The outcomes of cytotoxicity assay, carried out in triplicates of GPEE = Ginger Peel Ethanol Extract, PEF = Pet Ether Fraction, CF $=$ Chloroform Fraction, EAF $=$ Ethyl Acetate Fraction, AMF = Aquas Methanol Fraction, AGF $=$ Amino Group Fraction, CGF = Carboxylic Group Fraction, PHGF $=$ Phenolic Group Fraction, NCF = Neutral Compound Fraction, revealed that $\mathrm{PHGF}$ and $\mathrm{PEF}$ triggered an increase in percentage death of shrimps in a dose-dependent manner (Figure 2[C]). The $\mathrm{LC}_{50}$ of PHGF was found to be $18 \mu \mathrm{g} / \mathrm{ml}$, which was threefold higher than that of synthetic standard podophyllotoxin, i.e., $50 \mu \mathrm{g} / \mathrm{ml}$, while PEF showed little bit lesser response $(21 \mu \mathrm{g} / \mathrm{ml})$ in comparison to PHEF but which also two and half fold higher than standard.

\section{Antimitotic activity}

PHGF showed significant reduction in the mitotic index of onion root tips with increase in concentration (Figure 2[D]). Antimitotic activity was found to be significant at $10 \mathrm{mg} / \mathrm{ml}$ and $5 \mathrm{mg} / \mathrm{ml}$ of PHGF $(0.02 \pm$ $0.02 ; p<0.05)$ when equated with the control mitotic index $(0.43 \pm 0.02)$ and was also more than that of standard cyclophosphamide $(0.04 \pm 0.01$; $p<0.05)$.
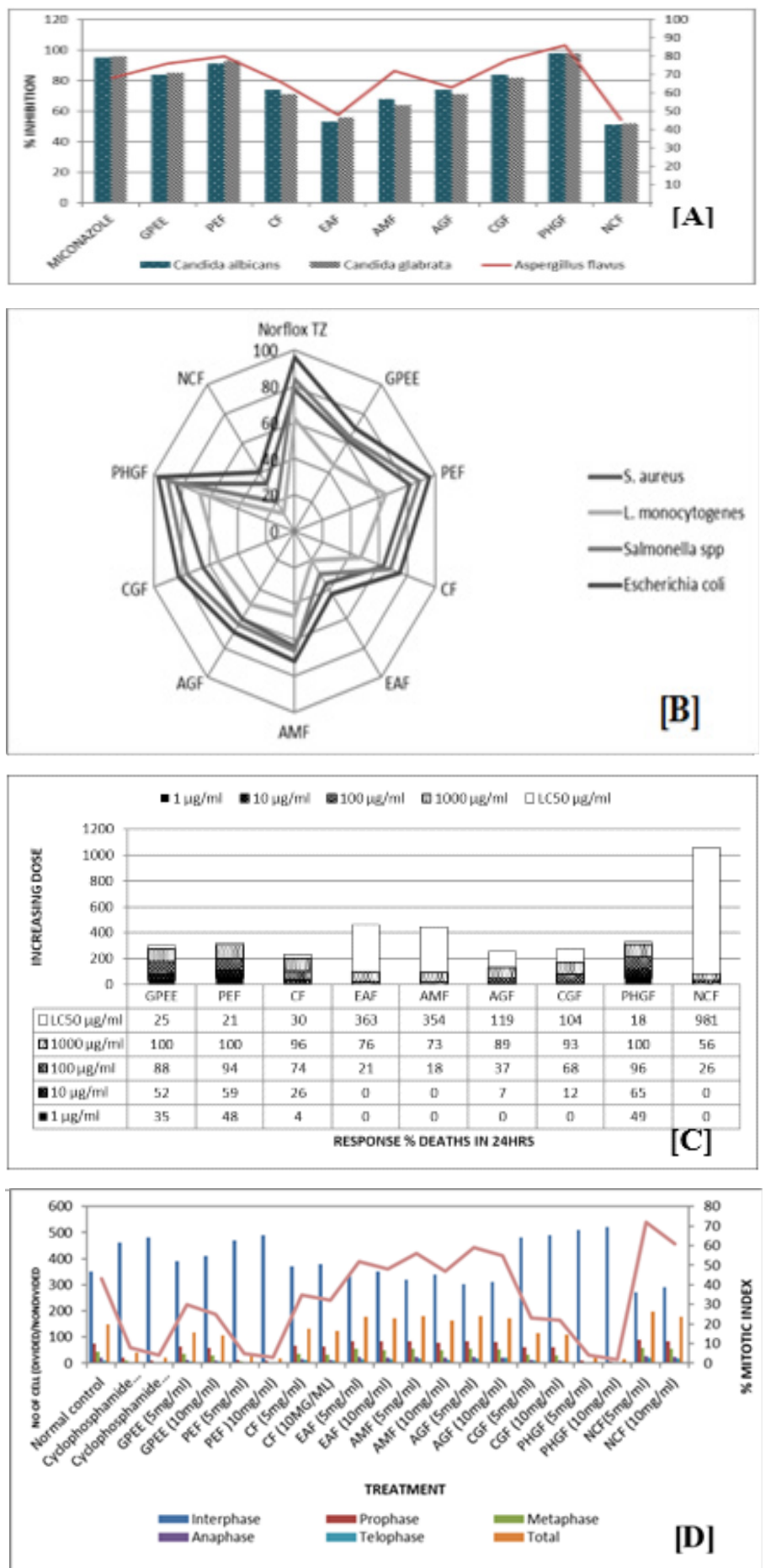

Figure 2: $[\mathrm{A}]$ Antifungal activity study and comparison. [B] Antibacterial activity study and comparison. [C] Cytotoxicity assay. [D] Antimitotic activity. GPEE = GINGER PEEL ETHANOL EXTRACT, PEF = PET ETHER FRACTION, $\mathrm{CF}=\mathrm{CHLOROFORM} F \mathrm{FACTION}, \mathrm{EAF}=\mathrm{ETHYL} \mathrm{ACETATE} \mathrm{FRACTION}, \mathrm{AMF}=$ AQUAS METHANOL FRACTION, AGF $=$ AMINO GROUR FRACTION, CGF $=$ CARBOXILIC GROUP FRACTION, PHGF = PHENOLIC GROUP FRACTION, NCF $=$ NUTRAL COMPOUND FRACTION

\section{Antiproliferative activity}

\section{a) HSF1 inhibition assay}

After $24 \mathrm{hr}$ of heat shock took the results of fractions of ginger peel extract activity on HCT116 cell. It showed very good GFP reading. From this 
reading I understood that pet ether extract of ginger peels extract and its Pet ether fraction and also its 2 isolated compounds (6-shogaol and 6-gingerol) have good HSF1 inhibition activity and creating apoptosis. 6-shogaol showed good GFP at $10 \mu \mathrm{g} / \mathrm{ml}$ and 6-gingerol compound good GFP at only $5 \mu \mathrm{g} / \mathrm{ml}$ (Figure 3[A]).

\section{b) MTT Assay}

In MTT assay cell viability was showing $\pm 54 \%$ in ginger peel extract sample dose of $100 \mu \mathrm{g} / \mathrm{ml}$. When the pet ether fraction of ginger peel extract was tested, result showed the $\pm 96 \%$ cell death in dose of $100 \mu \mathrm{g} /$ $\mathrm{ml}$ (Figure 3[B]).

\section{Cell viability activity screening by yeast model}

The results found by these two methods are not the same. In the case of the spotting test, $1 \mathrm{~h}$ incubation of cells with $12.5 \mu \mathrm{g} / \mathrm{ml}$ pet ether fractions causes $50 \%$ inhibition of growth. An assessment of these results with those obtained by the CFU method shows a significant alteration. In the case of the CFU method, it was noted a complete growth reduction of the wild type strain $99 \%$. The differences so observed in the results obtained. These two methods may be explained in two ways (Figure 4):

A) It may reduce direct contact with oxidants and facilitate growth of some cells which are protected by other cells.

B) Out of all the cells, the observed growth was marked in the test even if it consisted in growth of few cells. We observed cell viability of $90 \%$, $60 \%$ and $94 \%$ in the case of the wild-type strain. Our results by using methylene blue dye showed that after exposure to oxidants, there are few cells that are unable to reproduce but they are still alive in nature (Figure 4).

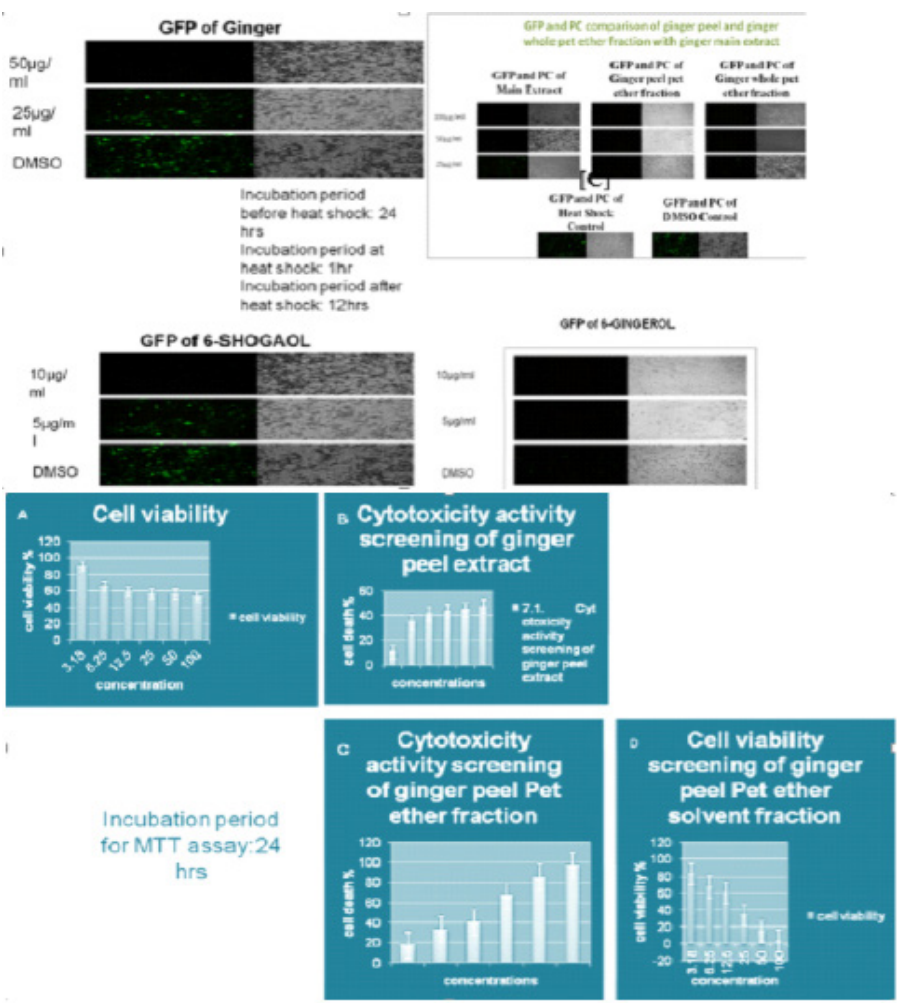

Figure 3: [A] GFP of Ginger rhizome extract, GFP and PC comparison of ginger peel and ginger rhizome pet ether fraction with ginger main extract. GFP of 6-shogaol, GFP of 6-Gingerol. [B] Cell viability and cytotoxicity activity screening of ginger rhizome peel extract and fractions cell death vs concentrations in MTT assay.
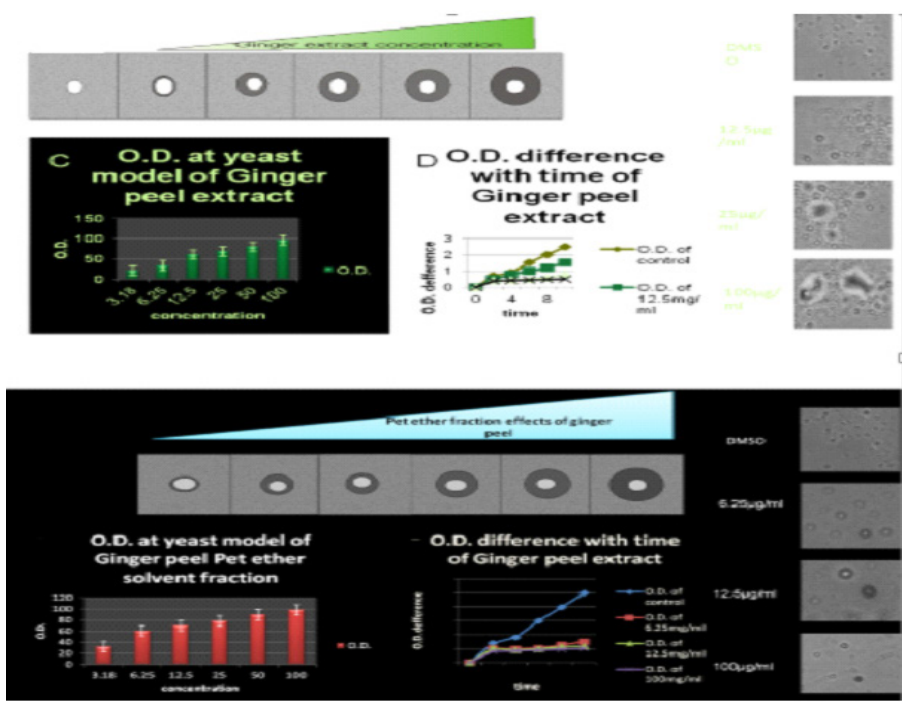

Figure 4: O.D. at yeast model with time variations screening of ginger rhizome peel extract and fractions O.D. vs concentration and O.D. vs time. pet ether fractions effect on yeast model.

\section{DISCUSSION}

The results of phytochemical analysis showed the presence of alkaloids (34.6\%), flavonoids (4.8\%), glycosides $(2.4 \%)$, triterpenoids $(22.2 \%)$ and phenolic content (36\%) in Ginger peel extract and alkaloids (0\%), flavonoids (1.8\%), glycosides (1.0\%), triterpenoids (12.4\%) and phenolic content $(84.8 \%)$ in PEF. Good results obtained for the antifungal activity ${ }^{3,10}$ of the extract and subsequent fractions derived from Zingiber officinale Linn. peel against the tested pathogens, which are showing good antifungal activity in the study. Also the extract and subsequent fractions derived from Zingiber officinale Linn. peel displayed a strong antibacterial activity ${ }^{3}$ against the tested organisms. The $\mathrm{LC}_{50}$ of PHGF was found to be $18 \mu \mathrm{g} / \mathrm{ml}$, which was threefold higher than that of synthetic standard podophyllotoxin, i.e., $50 \mu \mathrm{g} / \mathrm{ml}$, while PEF showed little bit lesser response $(21 \mu \mathrm{g} / \mathrm{ml})$ in comparison to PHEF but which also two and half fold higher than standard. ${ }^{12,13}$ PHGF showed significant reduction in the mitotic index of onion root tips with increase in concentration. Antimitotic activity was found to be significant at $10 \mathrm{mg} /$ $\mathrm{ml}$ and $5 \mathrm{mg} / \mathrm{ml}$ of PHGF $(0.02 \pm 0.02 ; P<0.05)$ when equated with the control mitotic index $(0.43 \pm 0.02),{ }^{15,16}$ and was also more than that of standard cyclophosphamide $(0.04 \pm 0.01 ; P<0.05)$. pet ether extract of ginger peels extract and its Pet ether fraction and also its 2 isolated compounds (6-shogaol and 6-gingerol) have good HSF1 inhibition activity and creating apoptosis. ${ }^{16,17} 6$-shogaol showed good GFP at $10 \mu \mathrm{g} /$ $\mathrm{ml}$ and 6-gingerol compound good GFP at only $5 \mu \mathrm{g} / \mathrm{ml}$. In MTT assay cell viability was showing $\pm 54 \%$ in ginger peel extract sample dose of $100 \mu \mathrm{g} / \mathrm{ml}$. When the pet ether fraction of ginger peel extract was tested, result showed the $\pm 96 \%$ cell death in dose of $100 \mu \mathrm{g} / \mathrm{ml}$. We observed cell viability of $90 \%, 60 \%$ and $94 \%$ in the case of the wild-type yeast strain. In consideration of the two presented methods fail to control whether the cells incapable to reproduce are dead, an alternative method was adopted, time-lapse photo microscopy of separate yeast cells ${ }^{19,20}$ in the presence of the vital dye Methylene blue is a dye absorbed by cells; metabolically lively cells are able to pump it out and endure colourless, (Figure 4) but dead cells are stained blue. Cells unable to reproduce were often mistakenly regarded as dead. These differences of colours were observable only after $8 \mathrm{~h}$ of culture, whereas they were not visible after $24 \mathrm{~h}$. Cells bright to replicate and their offspring produce a colony, thereby completely masking the occurrence of the nondividing and 
dead cells. A high number of dead cells was noted in the circumstance of incubation of the yeast cells with pet ether fractions, while a lower number was noted in the circumstance of incubation with another fractions. This method even nevertheless not a quantitative one, has an absolute advantage in comparison to the CFU method being simple and fast, permitting the dead cells to be distinguished and counted and also permitting differentiation between the alive cells that are able and unable to reproduce.

In comparison to the cell viability extent process based on the cell growth, the procedures based on colorimetric or fluorescent dyes are much quicker and give more quantifiable results by using methylene blue. The use of these dyes allows for analysis of individual yeast cells which penetrates into every cell. Living cells enzymatically decrease the dye to a colourless product and become unstained, but the dead cells are stained blue. We observed cell viability of $90 \%, 60 \%$ and $94 \%$ in the case of the wild-type strain. ${ }^{21,22,24}$ Our results by using methylene blue dye showed that after exposure to oxidants, there are few cells that are unable to reproduce but they are still alive in nature (Figure 4).

\section{CONCLUSION}

So, evaluating all these above results, we can easily get a conclusion that Pet ether fraction and 2 isolated compounds (6-shogaol and 6-gingerol) from Pet ether fraction have good anticancer drug potentiality which fraction was isolated from biowaste peel of Zingiber officinale Linn.

\section{ACKNOWLEDGEMENT}

This research was carried out in three parts. (1) Division of Molecular Medicine, Bose Institute, Kolkata under the guidance of Dr. Mahadeb Pal helped us to carry out cell line study. (2) Management of Akanksha Herbal Care Pvt. Ltd. Company helped us to carry out the yeast model study. (3) Authority of Jadavpur University, Kolkata helped us to carry out the studies.

\section{CONFLICT OF INTEREST}

The authors declare that there is no conflict of interest.

\section{REFERENCES}

1. Jamie M, Stagl LC, Bouchard SC, Lechner BB, Blomberg LM, Gudenkauf $\mathrm{DR}$, et al. Long-term psychological benefits of cognitive-behavioral stress management for women with breast cancer: 11-year follow-up of a randomized controlled trial. ACS Journals. 2015;6(1):1873-81.

2. Onitilo MO, Sanni LO, Daniel IO, Dixon AGO. Physicochemical and functional properties of native starches from cassava varieties in Southwest Nigeria. JFAE. 2007;5(3):108-14.

3. Shaileyee D, Anup KD, Subhash CM. Evaluation of Antimicrobial Activities of Various Solvent Extracts of Ginger Rhizome Peels and Whole Ginger Rhizome without Peels. WJPR. 2017;6(16):1450-68.

4. Shaileyee D, Subhash CM. Effect of Process Parameters of Microwave Assisted Extraction (MAE) on Natural Product Yield from Onion Peel. IJPSR. 2015;6(8):3260-75

5. Shaileyee D. Optimization of Ultrasound-assisted Extraction of Total Flavonoids and Antioxidant properties from Trigonella foenum-graecum Seeds with Response Surface Methodology. IJPSR. 2013;4(11):4308-18.

6. Banerjee B, Bhardwaj LK, Agrawal N, Lalhlenmawia H, Datta S, Subhash CM, et al. Lupeol And Eugenol Enriched Fraction from Piper Betel Leaf Oil and Their Quantitative Estimation by HPTLC for Quality Control Purposes. EJPMR. 2018;5(8):352-5.

7. Aeschbacher M, Reinhardt CA, Zbinden G. A rapid cell-membrane permeability test using fluorescent dyes and flow-cytometry. Cell Biol Toxicol. 1986;2(2):24755.

8. William CE. Phytochemistry. Trease and Evans Pharmacognosy. London New York Philadelphia St Louis Sydney Toronto: Elsevier. 2009;133-65.

9. Longo VD, Shadel GS, Kaeberlein M, Kennedy B. Replicative and chronological aging in Saccharomyces cerevisiae. Cell Metab. 2012;16(1):18-31.

10. Ansehn S, Nilsson L. Direct membrane-damaging effect of ketoconazole and tioconazole on Candida albicans demonstrated by bioluminescent assay of ATP Antimicrob Agents Chemother. 1984;26(1): 22-5.

11. Nilanjan G, Asif A, Rituparna G, Shaileyee D, Subhash CM, Mahadeb P. Chronic Inflammatory Diseases: Progress and Prospect with Herbal Medicine. Current Pharmaceutical Design. 2016;22(2):247-64.

12. Castro V, Augusto F, Mariani D, Panek AD, Araujo EEC, Pereira MD. Cytotoxicity mechanism of two naphthoquinones (menadione and plumbagin) in Saccharomyces cerevisiae. PLoS One. 2008;3(12):1-6.

13. Obrien J, Wilson I, Orton T, Pognan F. Investigation of the Alamar Blue (resazurin) fluorescent dye for the assessment of mammalian cell cytotoxicity. Eur J Biochem. 2000;267(17):5421-6.

14. Chaitanya MVNL, Jose A, Ramalingam P, Subhash CM, Kumar PN. Multitargeting cytotoxic drug leads from mushrooms. APJTM. 2019;12(12):531-6.

15. Bapat P, Nandy SK, Wangikar P, Venkatesh KV. Quantification of metabolically active biomass using methylene blue dye reduction test (MBRT): Measurement of CFU in about 200s. J Microbiol Methods. 2006;65(1):107-16.

16. Shaileyee D, Subhash CM. Cytotoxicity of Flavonoids analyzed using Different Cell Lines from The Onion Pell (Allium cepa). NSHM Journal of Pharmacy and Health Care Management. 2015;6:10-6.

17. Rashid H, Bharadwaj D, Majumder S, Mandal V, Pal M, Subhash CM, et al. Antioxidant and Anticancer Activity of Extract and Fractions Obtained from Diospyros Melanoxylon Roxb. Leaves and Correlation with Their Polyphenolic Profiles. IJPPS. 2018;10(11):6-16.

18. Czekanska EM. Assessment of cell proliferation with resazurin-based fluorescent dye. Methods Mol Biol. 2011;740:27-32.

19. Bilinski T, Lukaszkiewicz J, Sledziewski A. Hemoprotein formation in yeast. 4 Demonstration of anaerobic catalase synthesis in cz1 mutant of Saccharomyces cerevisiae. Biochem Biophys Res Commun. 1978;83(3):1225-33.

20. Koziol S, Zagulski M, Bilinski TA, Bartosz G. Antioxidants protect the yeast Saccharomyces cerevisiae against hypertonic stress. Free Radical Res. 2005;39(4):365-71.

21. Fannjiang $Y$, Cheng WC, Lee SJ. Mitochondrial fission proteins regulate programmed cell death in yeast. Genes Dev. 2004;18(22):2785-97.

22. Kwolek MM, Bednarska S, Bartosz G, Bilinski T. Acrolein toxicity involves oxidative stress caused by glutathione depletion in the yeast Saccharomyces cerevisiae. Cell Biol Toxicol. 2009;25(4):363-78.

23. Zheng K, Pan JW, Ye L. Programmed cell death-involved aluminium toxicity in yeast alleviated by antiapoptotic members with decreased calcium signals. Plant Physiol. 2017;143(1):38-49.

24. Nikolova M, Savova I, Marinov M. An optimised method for investigation of the yeast viability by means of fluorescent microscopy. J Cult Collect. 2002;3:66-71.

25. Marchi E, Cavalieri D. Yeast as a model to investigate the mitochondrial role in adaptation to dietary fat and calorie surplus. Genes Nutr. 2008;3(3-4):159-66.

26. Minois N, Frajnt M, Wilson C, Vaupel JW. Advances in measuring lifespan in the yeast Saccharomyces cerevisiae. P Natl Acad Sci USA. 2005;102(2):402-6.

27. Ludovico P, Sansonetty F, Corte-Real M. Assessment of mitochondrial membrane potential in yeast cell populations by flow cytometry. Microbiology. $2001 ; 147(12): 3335-43$

28. Mirisola MG, Braun RJ, Petranovic D. Approaches to study yeast cell aging and death. FEMS Yeast Res. 2014;14(1):109-18.

29. Painting K, Kirsop B. A quick method for estimating the percentage of viable cells in a yeast population, using methylene-blue staining. World J Microbio Biotechnol. 1990;6(3):346-7.

30. Madeo F, Frohlich E, Ligr M, Grey M, Sigrist SJ, Wolf DH, et al. Oxygen stress: A regulator of apoptosis in yeast. J Cell Biol. 1999;145(4):757-67.

Article History: Submission Date : 12-08-2020; Revised Date : 07-11-2020; Acceptance Date : 01-01-2021.

Cite this article: Das S, Manda SC. From Biowastes to Potent Anticancer Leads Evaluation from Peel of Zingiber officinale Linn. Int. J. Pharm. Investigation. 2021;11(1):46-51. 